\title{
PALABRAS DE AGRADECIMIENTO AL RECIBIR EL PREMIO IBEROAMERICANO DE LETRAS “JOSÉ DONOSO” 2007
}

\author{
Miguel Barnet $(*)$
}

Todo pueblo que se niega a sí mismo está en trance de suicidio. Lo dice un refrán afrocubano: "Chivo que rompe tambó con su pellejo paga", y lo afirmó el gran magíster de la antropología latinoamericana don Fernando Ortiz en el prólogo de los Cuentos Negros de Lydia Cabrera en 1940, el año en que nací.

Formado en una sociedad semicolonial y con la orientación de seguir los pasos de la generación que me precedió hacia los encantos de la tierra prometida, cuando leí esas palabras tan centellantes, mi vida tomó un giro radical, que junto al advenimiento de la Revolución Cubana me hizo tomar conciencia de mi propia identidad.

Anclé mi nave deliberadamente y con certera brújula en las arenas hondas del Caribe que me vio nacer. Fue un proceso difícil no exento de contradicciones, que me permitió contribuir a la edificación de un corpus literario cuya finalidad fue la de rescatar la voz de la llamada gente sin historia. Esa voz que había sido escamoteada por la historia oficial y que yo, perplejo, no entendía cómo no había sido reivindicada.

No sólo la antropología y sus enfoques para mí novedosos y reveladores sino el ideario cubano de tradición ética y sus programas sociales me aportaron una visión que mis predecesores no poseyeron y de las cuales yo me apropié ávido de afán de justicia y obsesionado por atender las claves secretas de mi país. Cuba se convirtió en una obsesión y comenzó mi labor de sondeo y búsqueda en los intersticios del tejido social que había tenido ante mis ojos y que no veía.

La literatura, esa esencia misteriosa que lo puede todo, que nos hace ver hasta del otro lado de la luz, y mis acercamientos a las ciencias sociales, me dieron las

(*) Escritor cubano, galardonado con el Premio Iberoamericano de Letras “José Donoso" 2007, otorgado por Santander-Santiago y la Universidad de Talca. 
herramientas para elaborar ese producto híbrido que en 1966 se me ocurrió calificar de novela testimonio, a la que algunos dan categoría de género y que yo digo que es sólo una materia prima para moldear. Establecí una profunda complicidad con la historia y con mis personajes, nunca ajeno, jamás, a la vibración de la poesía que es la verdadera piedra de toque de mi obra y, desde luego a la vocación fundacional de contribuir a la compresión de un concepto más integral y coherente de nación.

Con el convencimiento de que todas las vidas, aun las más ocultas y aparentemente apagadas, son importantes, hallé a mis personajes: esclavos, cimarrones, coristas de un teatro vernáculo estigmatizado, gallegos que en alpargatas y sacos de lana huían de la bruma, el hambre y el servicio militar, emigrantes cubanos que buscaban el bienestar económico en urbes del norte, criaditas inocentes que se enamoraban de señoritos atildados, travestis o tías escandalosas untadas de extracto de amapola en las axilas. Lo que sí me obligó a una búsqueda más difícil fue el lenguaje, un lenguaje que no traicionara ni desvirtuara la materia confesional, tan delicada y peligrosa, de sus vidas. Para eso estaba, como guardián de castillo, y a mis pies la poesía. El lenguaje aparecía ahí, no como caricatura sino como naturaleza; las palabras y su entonación, sonora o disonante, dueñas de su sentido más recóndito, dueñas de sí mismas. Y eran las palabras que debajo de la estructura, hacían vibrar y daban su sentido mayor al lenguaje. Palabras que he puesto a pelear en frases construidas al azar, en rompecabezas irrepetibles, sin sospechar que estaba creando formas poéticas. He sido avaro de ellas, me he desvelado en sus sonidos y sus formas, he vivido con ellas como en una música cuya tierra es mía.

Más que crear, más que inventar lo que he hecho en mis prosas es recrear, reinventar incluso una tradición que iba a morir, actuar como un resonador de esas voces, como un reflector que va iluminando esos pliegues interiores, esas zonas oscuras, haciendo aparecer con luminosidad propia figuras que habían estado ahogadas en lo opaco. Este es el único mérito de la novela testimonio que he contribuido a crear.

Hay quien colecciona sellos, aves exóticas o monedas etruscas, yo he coleccionado vidas ajenas y no con un capricho de coleccionista sino con la pasión de bucear en el pozo de la microhistoria convencido de que sólo el escritor puede salvaguardar la memoria colectiva frente a la avalancha tecnológica de la modernidad que ha convertido en robots a una parte importante de la especie humana. Es posible que este sea un acto de fe, pero no me avergüenzo de él, sino por el contrario es mi mayor orgullo.

Uno ha creído que el fin de algo se precipita cuando lo que se anuncia es el comienzo. Como escribió Juan Rulfo: "Se oye que ladran los perros y se siente en el aire el olor a humo, y se saborea ese olor de la gente como si fuera una esperanza". Alrededor de esa esperanza giramos todos.

El hecho de recibir un premio con el nombre de José Donoso resulta una sorpresa por partida doble. Por un lado, lo inesperado de la noticia desata la emoción, y la incredulidad da paso a la certeza: el nombre del premio viene de inmediato a buscar momentos retrospectivos, en ese caso lecturas que han sido viaje sin escala a una de 
las zonas, tan venturosas como reveladoras, de la creación verbal. Por el otro, el nombre mismo de José Donoso, su trayectoria literaria sin concesiones a la hora del compromiso con el rigor más afilado, con la disciplina más pertinaz, con la imaginación más arriesgada: el autor de una obra cuya excelencia, en los derroteros de la narrativa latinoamericana del siglo XX, está asentada en títulos legendarios como son Coronación, El obsceno pájaro de la noche, El lugar sin límites y Casa de campo, entre otros que confirman su andadura a lo largo de varias décadas en las que, de modo muy particular, el nombre suyo formó parte de una legión de escritores ya devenidos clásicos contemporáneos.

En el panorama de la literatura latinoamericana del siglo XX, su nombre significa la propiedad más profunda y luminosa de la invención verbal. En sus memorias lo define así: "No tuve libertad de elección porque un escritor no elige ni su voz, ni su mundo, ni su protesta, ni su modo de manifestarla; lo que fue creciendo desde mis palabras, pronto lo comprobé, me estaba asignado antes de que yo naciera, atándome a cierto dolor de perfil inconfundible". Que ese nombre, ahora en el fiel de un premio que le recuerda y le consagra con donaire, venga a reconocer los trabajos y los días de alguien que, desde muy lejos en tiempo y espacio, le admiró al calor de sus lecturas, es algo que excede cualquier fantasía. Ser distinguido de esa manera es un lujo del alma; ello posibilita estar con José Donoso en el lugar sin límites. 